\title{
Inflammatory Cytokines Interleukin-1 $\beta$ and Tumour Necrosis Factor- $\alpha$ - Novel Biomarkers for the Detection of Periodontal Diseases: a Literature Review
}

\author{
Francisco Isaac Fernandes Gomes, ${ }^{1}$ Maria Gerusa Brito Aragão1, Francisco Cesar Barroso \\ Barbosa $^{1}$, Mirna Marques Bezerra ${ }^{2}$, Vicente de Paulo Teixeira Pinto ${ }^{2}$, Hellíada Vasconcelos Chaves ${ }^{1}$ \\ ${ }^{1}$ Faculty of Dentistry, Federal University of Ceará, Sobral, Ceará, Brazil. \\ ${ }^{2}$ Faculty of Medicine, Federal University of Ceará, Sobral, Ceará, Brazil.
}

\author{
Corresponding Author: \\ Hellíada Vasconcelos Chaves \\ Faculty of Medicine of Sobral, Federal University of Ceará \\ Avenida Comandante Maurocélio Rocha Pontes, 100 \\ Derby - CEP: 62.042-280, Sobral, Ceará \\ Brazil \\ Phone: 55 88-3611-2202 \\ Fax: 55 88-3611- 8000 \\ E-mail: helliadachaves@yahoo.com.br
}

\begin{abstract}
Objectives: The article aims to discuss the IL- $1 \beta$ and TNF- $\alpha$ potential use as salivary biomarkers of periodontal diseases pathogenesis and progression.

Material and Methods: This literature review has been registered in PROSPERO database with following number: CRD42016035729. Data investigation was performed on PubMed database as the main source of studies. The following search terms were used: "salivary biomarkers", "periodontal diseases", "TNF-alpha", "Interleukin-1 beta". Clinical trials and animal experimental models of periodontal disease were included in the discussion. In regards to inclusive dates, published studies from January 2006 to December 2015 were considered in this review along with the mentioned inclusion criteria.

Results: IL- $1 \beta$ and TNF- $\alpha$ salivary levels increased in diseased groups, they were associated with onset and disease severity, and their levels reduced in response to periodontal therapy. IL- $1 \beta$ and TNF- $\alpha$ could be promising biomarkers in the detection of periodontal diseases.

Conclusions: The use of a salivary cytokine-based diagnosis appears to be a screening method capable of diagnosing periodontal diseases in an early fashion, establishing an era of individualized clinical decisions.
\end{abstract}

Keywords: biological markers; interleukin-1beta; periodontal diseases; TNF-alpha.

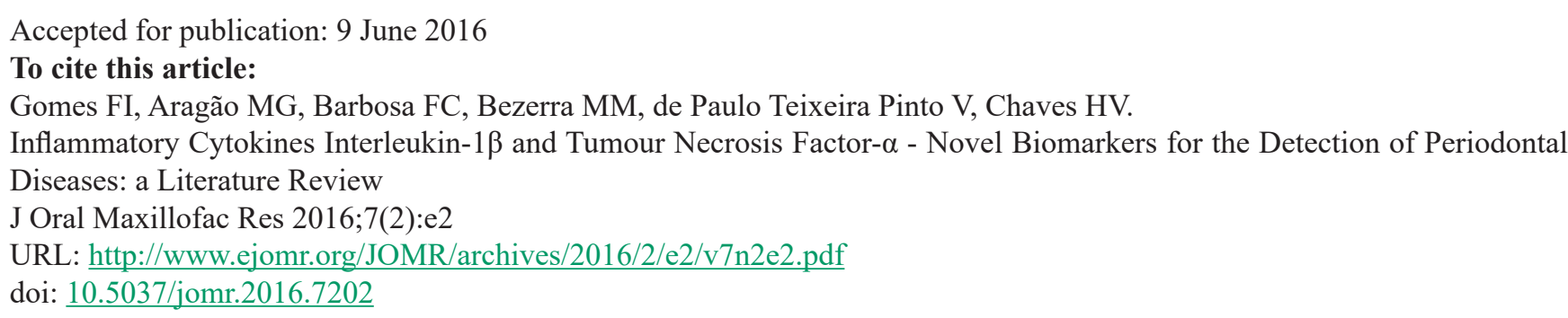




\section{INTRODUCTION}

Periodontal diseases usually refer to inflammatory disorders that are caused by pathogenic bacteria in the sub gingival biofilm in association with impaired host immune response and connective tissue breakdown. The bacterial challenge exacerbates the cytokine production by the gingival epithelium, resulting in an uncontrolled inflammation that leads to tooth loss in adults from different populations [1-3].

The prevalence of these diseases increases with aging, longer retention of teeth, and increased incidence of obesity and diabetes among the population. The prevalence demonstrates an increasing trend and a correlation with numerous comorbidities. Thus, it is relevant to develop new methods capable of detecting these diseases in early stages and following up their progression [4].

Increased cytokine levels in the saliva and gingival crevicular fluid of patients affected by periodontal diseases are a hallmark of the initiation and maintenance of these pathologies. Salivary fluid is an exocrine secretion consisting of approximately 99\% water containing electrolytes, for instance, sodium, potassium, calcium, chloride, magnesium, bicarbonate, phosphate and proteins, such as enzymes, immune globulins and other antimicrobial factors, mucosal glycoproteins, traces of albumin, and some polypeptides and oligopeptides of importance to the oral health. Saliva is critical for the preservation and maintenance of the oral tissues, and it has been used as a source of non-invasive investigation of metabolism and for the elimination of many drugs [5]. Thus, it should contain biomarkers for the unique physiological aspects of periodontal diseases, which means that qualitative changes in the biomarkers composition might have diagnostic and therapeutic significance [6-7].

Many contributing inflammatory mediators have been associated with the pathogenesis and progression of periodontal diseases, such as the inflammatory cytokines interleukin-1 beta (IL-1 $\beta$ ) and tumour necrosis factor-alpha (TNF- $\alpha$ ), which seem to play an important role in the focal immunopathology of periodontal diseases. IL-1 $\beta$ secretion pathway is complex, as it requires molecular signals to occur such as exposure to cellular danger or stress signals, culminating in an assembly of inflammasomes, molecular platforms that mediate action of caspase-1 and are essential for the activation of IL-1 $\beta$ [ $\underline{8}$.

Furthermore, TNF- $\alpha$ and IL-1ßinduce bone resorption and up-regulate prostaglandin $\mathrm{E}_{2} \quad\left(\mathrm{PGE}_{2}\right)$ and collagenases secretion and are produced by many cell types including macrophages, neutrophils, keratinocytes, fibroblasts, NK cells, T and B cells in the periodontium. These cytokines induce the up-regulation of adhesion molecules on leucocytes and endothelial cells, stimulating the production of chemokines that recruit circulating leucocytes to sites of inflammation, and inducing expression of other inflammatory mediators that potentiate inflammatory responses. Studies have indicated that their levels contribute to the pathogenesis of periodontitis since higher serum levels of IL-1 $\beta$ and TNF- $\alpha$ were detected in periodontitis patients [8-9]. Thus, based on literature data available, we aim to provide a rationale for the use of IL- $1 \beta$ and TNF- $\alpha$ as biological markers of periodontal diseases.

\section{MATERIAL AND METHODS Protocol and registration}

This review was conducted following the PRISMA (Preferred Reporting Items for Systematic Reviews and Meta-analyses) statement [10] and it was registered on the international prospective register of systematic reviews 'PROSPERO' [11]. The protocol can be accessed at:

http://www.crd.york.ac.uk/PROSPERO/display record.asp?ID=CRD42016035729

\section{Focus question}

The focus question of this review is whether or not the salivary levels of the inflammatory cytokines IL- $1 \beta$ and TNF- $\alpha$ could be associated with clinical evidence of periodontal tissue breakdown so that they could be used as biological markers of periodontal diseases.

\section{Types of publications}

The review included studies on humans and animals published in the English language. Letters, editorials, literature reviews, $\mathrm{PhD}$ theses, and abstracts were excluded.

\section{Types of studies}

The review included all human prospective follow-up studies and clinical trials, cohort studies, case-control studies, and animal studies published between January 2006 and December 2015, on the use of biological markers of periodontal tissue breakdown as diagnosis tool for periodontal diseases. Case report studies were excluded. 


\section{Information source}

The search strategy incorporated examinations of the electronic database PubMed (National Library of Medicine, NCBI) (www.ncbi.nlm.nih.gov/pubmed/).

\section{Search}

The PubMed database was explored through advanced searches. The search was conducted using the following key words either alone or combined: "salivary biomarkers", "periodontal diseases", "Tumour Necrosis Factor-alpha", "Interleukin-1 beta". The choice of keywords was intended to be broad, in order to collect as much relevant data as possible without relying on electronic means alone to refine the search results.

\section{Study selection}

The resulting articles were independently subjected to clear inclusion and exclusion criteria by two reviewers. They also compared decisions and resolved differences through discussion, consulting a third party, who was an experienced reviewer, when consensus was not reached.

\section{Inclusion and exclusion criteria}

Inclusion criteria for studies were:

- Studies in animal models of marginal periodontitis and case-control, cohort and prospective studies in humans;

- Studies that screened and compared salivary levels of IL-1 $\beta$ and/or TNF- $\alpha$ in at least two different experimental pools - control and diseased groups;

- Assessment of clinical parameters such as depth and bleeding on probe, radiographic evidence of bone loss, and salivary levels of IL- $1 \beta$ or TNF- $\alpha$ measured by enzyme-linked immunosorbent assay (ELISA).

Exclusion criteria for studies were:

- Case reports and literature reviews were excluded.

\section{Sequential search strategy}

Following the initial literature search, all article titles were screened to eliminate irrelevant publications, review articles, and case reports. Thereafter, the selected studies were excluded based on data obtained from screening the abstracts. The final stage of screening involved reading the full texts to confirm eligible studies based on the inclusion and exclusion criteria previously mentioned.

\section{Data collection process and data items}

Two different reviewers independently searched for studies on the aforementioned database adopting the described eligibility criteria. All the studies found were then crossed to exclude duplicated ones. As a result, 225 potential articles were obtained at first instance which in turns had their titles and abstracts read and categorised according to the type of studyanimal or clinical investigation. Considering the inclusive dates, 144 studies remained for further review, which consisted of the investigation of the association of cytokines IL-1 $\beta$ and TNF- $\alpha$ with periodontal diseases onset, progression, and severity. This final step led to the total of 15 articles which are reviewed and discussed here (Figure 1).

\section{Risk of bias in individual studies and across studies}

The Cochrane collaboration bias summary for potential bias was used to assess the quality of studies and identify papers with intrinsic flaws in method and design (Table 1) [12].

\section{Synthesis of results}

Relevant data of interest were collected and organised into Tables 2 and 3.

\section{Statistical analysis}

No meta-analyses could be performed due to the heterogeneity between the studies.

\section{RESULTS \\ Study selection}

Two investigators initially carried out the search for studies as presented in Figure 1. This initial search yielded 225 non-doubled references from PubMed database. In the stage of screening in accordance with the study selection process 'PRISMA 2009 Flow Diagram' as presented in Figure 1, titles and abstracts of the studies were read and they were selected in according to the type of study and inclusive dates adopted. At this stage, irrelevant titles and abstracts were excluded $(n=81)$ and 144 potential articles were further evaluated in order to find studies that associated the periodontal diseases onset, severity, and progression with salivary levels of IL- $1 \beta$ or TNF- $\alpha$. After checking articles for eligibility, a total of 15 studies full studies remained for further discussion whilst 129 ones were excluded due to no association of periodontal diseases activity with IL- $1 \beta$ or TNF- $\alpha$ levels. 


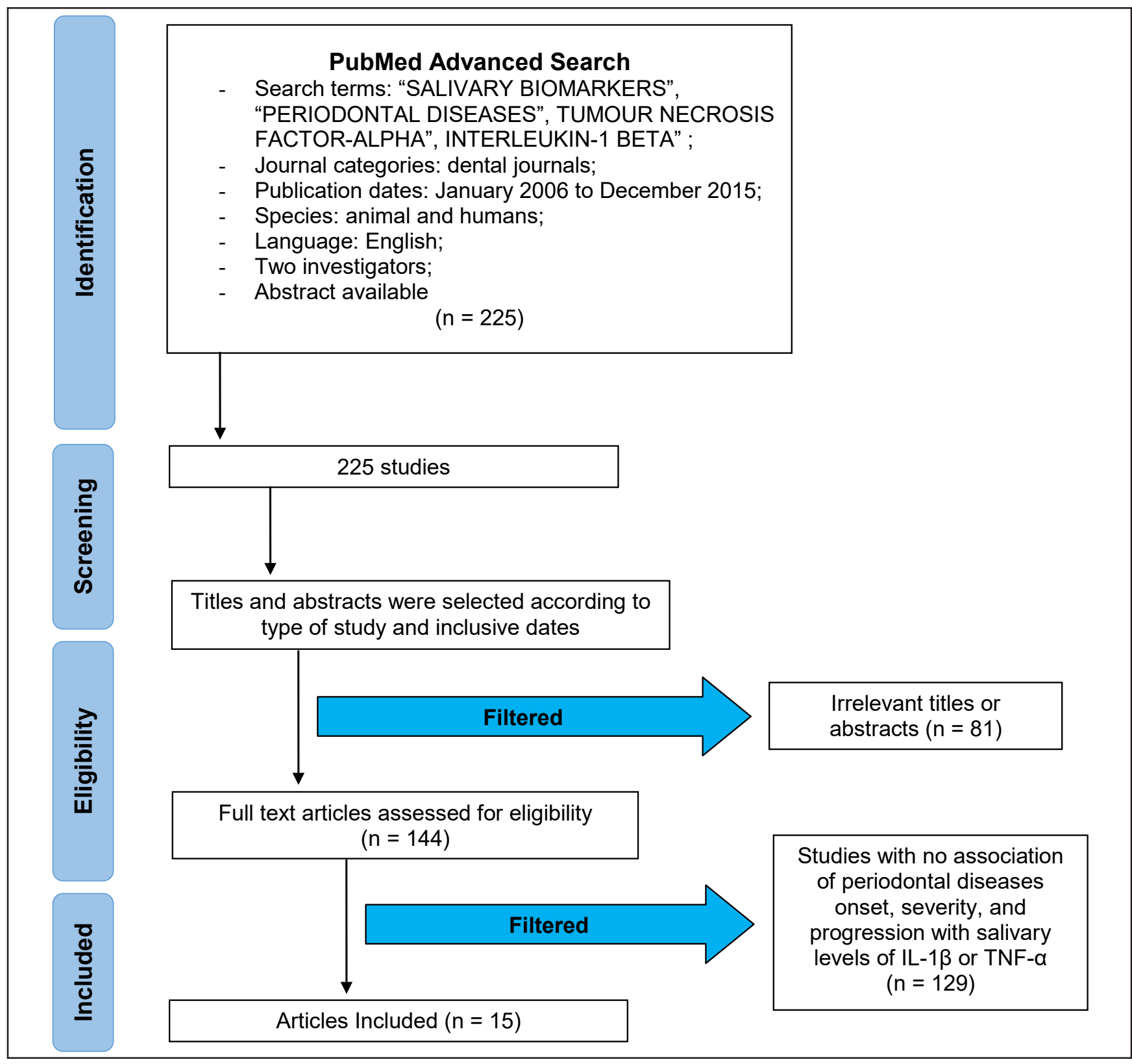

Figure 1. PRISMA flow diagram.

Table 1. Risk of bias table

\begin{tabular}{l|c|c|c|c|c|c|c}
\hline \multicolumn{1}{c|}{ Study } & $\begin{array}{c}\text { Year of } \\
\text { publication }\end{array}$ & $\begin{array}{c}\text { Random } \\
\text { sequence } \\
\text { generation }\end{array}$ & $\begin{array}{c}\text { Allocation } \\
\text { concealment }\end{array}$ & $\begin{array}{c}\text { Blinding of } \\
\text { participants } \\
\text { and personnel }\end{array}$ & $\begin{array}{c}\text { Blinding of } \\
\text { outcome } \\
\text { assessment }\end{array}$ & $\begin{array}{c}\text { Incomplete } \\
\text { outcome data } \\
\text { addressed }\end{array}$ & $\begin{array}{c}\text { Selective } \\
\text { reporting }\end{array}$ \\
\hline Sexton et al. [2] & 2011 & low risk & low risk & low risk & low risk & low risk & low risk \\
\hline da Costa et al. [3] & 2015 & low risk & low risk & low risk & low risk & low risk & low risk \\
\hline Frodge et al. [4] & 2008 & low risk & low risk & low risk & low risk & low risk & low risk \\
\hline Rosa et al. [7] & 2014 & low risk & unclear risk & unclear risk & unclear risk & unclear risk & low risk \\
\hline Ma et al. [13] & 2015 & low risk & low risk & low risk & low risk & low risk & low risk \\
\hline Zhu et al. [14] & 2015 & low risk & low risk & low risk & low risk & low risk & low risk \\
\hline Oh et al. [15] & 2015 & low risk & low risk & low risk & low risk & low risk & low risk \\
\hline Miller et al. [16] & 2006 & low risk & low risk & low risk & low risk & low risk & low risk \\
\hline Ng et al. [17] & 2007 & low risk & low risk & low risk & low risk & low risk & low risk \\
\hline Scannapieco et al. [18] & 2007 & low risk & low risk & low risk & low risk & low risk & low risk \\
\hline Reinhardt et al. [19] & 2010 & low risk & low risk & low risk & low risk & low risk & low risk \\
\hline Noh et al. [20] & 2013 & low risk & low risk & low risk & low risk & low risk & low risk \\
\hline Kato et al. [21] & 2014 & low risk & low risk & low risk & low risk & low risk & low risk \\
\hline Liao et al. [22] & 2014 & low risk & lnclear risk & unclear risk & low risk & low risk & low risk \\
\hline Singh et al. [23] & 2014 & low risk & low risk & low risk & low risk & low risk & low risk \\
\hline
\end{tabular}


Table 2. Studies investigating interleukin-1 $\beta$ (IL-1 $\beta$ ) expression and periodontal diseases

\begin{tabular}{|c|c|c|c|}
\hline Study & Study design & Results & Conclusions \\
\hline $\begin{array}{l}\text { Sexton } \\
\text { et al [2] }\end{array}$ & $\begin{array}{l}\text { 6-month case-controlled study of adults } \\
\text { with chronic periodontitis. }\end{array}$ & $\begin{array}{l}\text { IL-1 } \beta \text { levels decreased significantly in } \\
\text { response to periodontal therapy. }\end{array}$ & $\begin{array}{l}\text { Potential utility for monitoring } \\
\text { periodontal disease status. }\end{array}$ \\
\hline $\begin{array}{l}\text { Rosa et al. } \\
{[7]}\end{array}$ & $\begin{array}{l}\text { Analysis of proteome results using the } \\
\text { OralOme database }\end{array}$ & $\begin{array}{l}\text { IL- } 1 \beta \text { proposed to be promising but data } \\
\text { are scarce. }\end{array}$ & $\begin{array}{l}\text { Further quantitative proteomic studies } \\
\text { are needed. }\end{array}$ \\
\hline $\begin{array}{l}\text { Ma et al. } \\
{[13]}\end{array}$ & $\begin{array}{l}\text { Meta-analysis of } 20 \text { case-controlled } \\
\text { studies. }\end{array}$ & $\begin{array}{l}\text { Association of the interleukin-1 } \beta \\
(3953 / 4) \mathrm{C} \rightarrow \mathrm{T} \text { polymorphism with } \\
\text { chronic periodontitis in Asians. }\end{array}$ & $\begin{array}{l}\mathrm{IL}-1 \beta(3953 / 4) \mathrm{C} \rightarrow \mathrm{T} \text { polymorphism } \\
\text { probably increases the risk of chronic } \\
\text { periodontitis in Asians. }\end{array}$ \\
\hline $\begin{array}{l}\text { Zhu et al. } \\
{[14]}\end{array}$ & $\begin{array}{l}\text { Investigation of systemic and local } \\
\text { levels of IL-1 } \beta \text {, MCP-1, VEGF, PDGF in } \\
\text { patients with periodontitis and coronary } \\
\text { heart disease. }\end{array}$ & $\begin{array}{l}\text { IL-1 } \beta \text { concentrations in the serum and } \\
\text { gingival crevicular fluid of the three } \\
\text { diseased groups were significantly higher } \\
\text { than those in the control group. }\end{array}$ & $\begin{array}{l}\text { IL- } 1 \beta \text { could play a key role and can } \\
\text { be considered a biomarker in the } \\
\text { progression of coronary heart disease } \\
\text { and chronic periodontitis. }\end{array}$ \\
\hline $\begin{array}{l}\text { Oh et al. } \\
{[15]}\end{array}$ & $\begin{array}{l}\text { Effects of periodontal therapy on clinical } \\
\text { parameters and IL-1 } \beta \text { levels in patients } \\
\text { with chronic periodontitis. }\end{array}$ & $\begin{array}{l}\text { IL- } 1 \beta \text { concentration was lower at } 2 \text { and } 4 \\
\text { months after initial therapy at all sites. }\end{array}$ & $\begin{array}{l}\text { These results suggest that IL- } 1 \beta \text { level } \\
\text { in samples reflect disease severity. }\end{array}$ \\
\hline $\begin{array}{l}\text { Miller et al. } \\
{[16]}\end{array}$ & $\begin{array}{l}\text { Levels of IL-1 } \beta, \text { MMP- } 8 \text {, and OPG } \\
\text { in whole saliva of } 57 \text { adults in a case- } \\
\text { control trial. }\end{array}$ & $\begin{array}{l}\text { Mean levels of IL- } 1 \beta \text { in saliva were } \\
\text { significantly higher in case subjects than } \\
\text { in controls. }\end{array}$ & $\begin{array}{l}\text { Salivary levels of IL-1 } \beta \text { appear to serve } \\
\text { as biomarkers of periodontitis. }\end{array}$ \\
\hline $\begin{array}{l}\text { Ng et al. } \\
{[17]}\end{array}$ & $\begin{array}{l}\text { Alveolar bone loss and concentration of } \\
\text { host-derived bone resorptive factors in } \\
\text { saliva of } 110 \text { untreated dental patients in } \\
\text { a cross-sectional study. }\end{array}$ & $\begin{array}{l}\text { IL- } 1 \beta \text { levels associated with increased } \\
\text { bone loss score. }\end{array}$ & $\begin{array}{l}\text { Biomarkers in saliva may serve as } \\
\text { a useful tool to monitor and predict } \\
\text { periodontal diseases. }\end{array}$ \\
\hline $\begin{array}{l}\text { Scannapieco } \\
\text { et al. }[18]\end{array}$ & $\begin{array}{l}\text { Association of salivary biomarkers with } \\
\text { alveolar bone loss from } 1,256 \text { post- } \\
\text { menopausal women in a case-control } \\
\text { study. }\end{array}$ & $\begin{array}{l}\text { Positive association between alveolar } \\
\text { bone loss and salivary concentrations of } \\
\text { IL-1 } \beta \text {. }\end{array}$ & $\begin{array}{l}\text { Salivary biomarkers measured at } \\
\text { baseline may serve to predict future } \\
\text { alveolar bone loss. }\end{array}$ \\
\hline $\begin{array}{l}\text { Reinhardt } \\
\text { et al. [19] }\end{array}$ & $\begin{array}{l}\text { Correlation of salivary biomarkers and } \\
\text { bone resorption in a longitudinal trial. }\end{array}$ & $\begin{array}{l}\text { Increasing IL-1 } \beta \text { levels in the first year } \\
\text { were associated with increased odds of } \\
\text { subsequent periodontal attachment loss. }\end{array}$ & $\begin{array}{l}\text { Elevated biomarkers have the potential } \\
\text { to identify patients vulnerable to } \\
\text { periodontitis. }\end{array}$ \\
\hline
\end{tabular}

Table 3. Studies investigating tumour necrosis factor $-\alpha(\mathrm{TNF}-\alpha)$ expression and periodontal diseases

\begin{tabular}{|c|c|c|c|}
\hline Study & Study design & Results & Conclusions \\
\hline $\begin{array}{l}\text { da Costa } \\
\text { et al. [3] }\end{array}$ & $\begin{array}{l}\text { Identification of the on-going inflammatory } \\
\text { changes and novel biomarkers for } \\
\text { periodontitis in a case-controlled study. }\end{array}$ & $\begin{array}{l}\text { TNF- } \alpha \text { levels were elevated compared to } \\
\text { controls. }\end{array}$ & $\begin{array}{l}\text { TNF- } \alpha \text { levels could be of great } \\
\text { importance to the assessment of } \\
\text { disease progression. }\end{array}$ \\
\hline $\begin{array}{l}\text { Rosa et } \\
\text { al. [7] }\end{array}$ & $\begin{array}{l}\text { Analysis of proteome results using the } \\
\text { OralOme database. }\end{array}$ & $\begin{array}{l}\text { TNF- } \alpha \text { proposed to be promising but data are } \\
\text { scarce. }\end{array}$ & $\begin{array}{l}\text { Further quantitative proteomic studies } \\
\text { are needed. }\end{array}$ \\
\hline $\begin{array}{l}\text { Noh et } \\
\text { al. }[20]\end{array}$ & $\begin{array}{l}\text { Quantification TNF- } \alpha \text { levels of patients } \\
\text { with periodontitis. }\end{array}$ & TNF- $\alpha$ expression consistently high. & $\begin{array}{l}\text { Measurement of TNF- } \alpha \text { may be } \\
\text { beneficial in the identification of } \\
\text { patients with periodontitis. }\end{array}$ \\
\hline $\begin{array}{l}\text { Kato et } \\
\text { al. [21] }\end{array}$ & $\begin{array}{l}\text { Determine the effect of TNF- } \alpha \text { on invasion } \\
\text { of Porphyromonas gingivalis in gingival } \\
\text { epithelial cells. }\end{array}$ & $\begin{array}{l}\text { Invasion of } P \text {. gingivalis augmented by } \\
\text { stimulation with TNF- } \alpha \text { and inhibited by } \\
\text { treatment with an antibody to TNF receptor- } 1 \text {. }\end{array}$ & $\begin{array}{l}\text { Involvement of TNF- } \alpha \text { in the onset of } \\
\text { periodontal diseases. }\end{array}$ \\
\hline $\begin{array}{l}\text { Liao et } \\
\text { al. }[22]\end{array}$ & $\begin{array}{l}\text { Simulate the expression of TNF- } \alpha \text { of } \\
\text { periodontal tissues in rat periodontitis } \\
\text { model. }\end{array}$ & $\begin{array}{l}\text { TNF- } \alpha \text { expression of the periodontitis group } \\
\text { was significantly higher. }\end{array}$ & $\begin{array}{l}\text { TNF- } \alpha \text { expression reached higher } \\
\text { levels than control groups. }\end{array}$ \\
\hline $\begin{array}{l}\text { Singh et } \\
\text { al. [23] }\end{array}$ & $\begin{array}{l}\text { Evaluate the effect of type } 2 \text { diabetes } \\
\text { mellitus and smoking on salivary levels } \\
\text { of TNF- } \alpha \text { in patients with chronic } \\
\text { periodontitis. }\end{array}$ & $\begin{array}{l}\text { Data revealed higher levels of TNF- } \alpha \text { in } \\
\text { diabetic subjects followed by smokers, and } \\
\text { chronic periodontitis group. }\end{array}$ & $\begin{array}{l}\text { Diabetes and smoking exacerbated } \\
\text { salivary levels of TNF- } \alpha \text { in chronic } \\
\text { periodontitis cases. }\end{array}$ \\
\hline
\end{tabular}

\section{Exclusion of studies}

The reasons for excluding studies were irrelevant titles and abstracts were excluded $(n=81)$ and lack of association of periodontal diseases activity with IL-1 $\beta$ or TNF- $\alpha$ levels $(n=129)$.

\section{Study characteristics}

The studies chosen in this review were published between January 2006 and December 2015 and they were designed to show association of periodontal disease activity with IL- $1 \beta$ or TNF- $\alpha$ salivary levels through assessment of clinical parameters such as depth and bleeding on probe, radiographic evidence of bone loss, and salivary levels of IL- $1 \beta$ or TNF- $\alpha$ measured by enzyme-linked immunosorbent assay (ELISA). Most studies selected were performed in humans through prospective studies, but also experimental models of periodontitis in animals were included as they were designed to determine the role of these two specific cytokines in the pathogenesis of 
periodontal diseases. Tables 2 and 3 summarise the main characteristics of the selected studies in this review and they give more detail on specific aspects of each one individually.

\section{Synthesis of studies}

No meta-analysis was carried out as heterogeneity in the studies design.

\section{Risk of bias within studies}

Periodontal diseases heavily depend on the host immune response individually. In this scenario, it is predictable that salivary biomarkers could be expressed differently by a subject who over reacts to bacterial challenges, whereas the same levels of inflammatory cytokines could not be involved in the same extent of periodontal tissue loss in a different individual. Thus, the association of salivary levels of IL- $1 \beta /$ TNF- $\alpha$ and connective tissue breakdown has careful in order to validate the use of inflammatory biomarkers to diagnosis periodontal diseases as individual responses may change.

\section{Interleukin-1 $\beta$ as a biological marker of periodontal diseases}

Interleukin- $1 \beta$ is a resulting product of inflammatory and infectious stimuli, contributing to the development of an inflammatory condition. IL-1 $\beta$ genes encode precursor molecules which are turned to mature forms via interleukin- $1 \beta$ convertase activity, cleaving the human $35-\mathrm{kDa}$ IL-1 $\beta$ precursor between aspartic acid 116 and alanine 117 to generate the mature $17-\mathrm{kDa}$ cytokine. The IL-1 $\beta$ active form shows immune potentiating effects, mediating inflammatory responses, bone resorption, leading to apoptosis, cell proliferation and differentiation in response to inflammatory stimuli such as bacterial LPS, promoting recruitment of phagocytes, angiogenesis, epithelial cell repair, and regulation of cytokines and chemokine production by other immune cells at the site of infection or injury, being it an orchestrating cytokine during the immune response [13-15].

Many clinical studies reported the use of IL-1 $\beta$ present in saliva or gingival crevicular fluid as a potential biomarker of periodontal disease. Mean levels of salivary IL- $1 \beta$ were significantly higher in patients with periodontal disease than in controls, and they were correlated with individual clinical parameters indicative of periodontal disease. Further, combined elevated salivary levels of IL-1 $\beta$ and matrix metalloproteinase- 8 increased the risk of experiencing periodontal disease 45-fold [16]. In addition to this, salivary IL- $1 \beta$ levels were found in greater abundance in samples of 110 diseased untreated dental patients as opposed to interleukin-6 and $\mathrm{PGE}_{2}$ [17]. These results showed a greater degree of correlation between IL-1 $\beta$ salivary levels and periodontal disease status than any of the other screened mediators.

In 1,256-postmenopausal population, a 40-subject cohort with significant alveolar bone loss over a 5 -year period was compared to 40-age-matched control subjects having no alveolar bone loss. IL$1 \beta$, osteonectin, and hepatocyte growth factor were quantified in saliva collected at baseline by immunoassay. Positive association was observed between alveolar bone loss and IL-1 $\beta$ salivary concentrations rather than between the other biomarkers screened in saliva [18]. Also, in regards to the IL-1 $\beta$ potential to predict bone loss, increases in this cytokine levels during the first year of periodontal maintenance were associated with increased odds of subsequent (year 2) periodontal attachment loss [19]. These obtained data support the hypothesis that elevated gingival crevicular fluid biomarkers of inflammation hold promise in identifying patients vulnerable to progressive periodontitis.

In order to determine the profile response to periodontal therapy and the disease status, Sexton et al. [2] assessed longitudinally different salivary biomarkers of periodontitis. A 68-participant group with chronic periodontitis had IL-1 $\beta$, IL-8, MIP$1 \alpha$, MMP-8, OPG, and TNF- $\alpha$ salivary cytokine levels screened. Salivary levels of IL-1 $\beta$ reflected disease severity and response to therapy suggesting its potential utility for monitoring periodontal disease status. In addition, a study carried out by $\mathrm{Oh}$ et al. [15] screened IL-1 $\beta$ gingival crevicular fluid levels in 13 chronic periodontitis patients. The data obtained suggested that gingival crevicular fluid IL-1 $\beta$ levels reflect disease severity and response to treatment in case of chronic periodontitis.

Furthermore, studies by Zhu et al. [14] looked at the association between periodontal and coronary heart disease and how the inflammatory cytokine levels responded to this association. All the subjects assessed in this study were found to have a significant increase in the IL-1 $\beta$ levels in gingival crevicular fluid (Table 2). Hence, high salivary levels of IL-1 $\beta$ were associated with increased risk of periodontitis onset, progression, and severity given the role this cytokine plays in the periodontal disease pathogenesis, being it useful as a diagnosis biomarker. 


\section{Tumour necrosis factor- $\alpha$ as a biological marker of periodontal diseases}

TNF- $\alpha$ is a pleiotropic pro-inflammatory cytokine released by a variety of different cell types in response to various stimuli, including bacteria, parasites, viruses, cytokines and mitogens. It is involved in systemic and local inflammation via different signal pathways, inducing a broad range of genes. TNF- $\alpha$ regulates a host response to infection and its deregulation is implicated in the pathogenesis of numerous complex diseases, including periodontitis. This cytokine was shown to drive several biological processes such as induction of inflammatory mediators, for instance, matrix metalloproteases, chemokines and prostaglandins, endothelial cell activation and endothelial-leukocyte interactions, monocyte adhesion, mediating bone remodelling, and oxidative processes [20-21]

Since TNF- $\alpha$ plays a role in the development and maintenance of inflammatory diseases, its mediating effects on the development, progress, and maintenance of periodontal diseases would be expected to occur. Many clinical trials showed a correlation between high TNF- $\alpha$ levels and periodontitis, results that would enable researchers and clinical practitioners to diagnose and monitor periodontal disease progression. Salivary levels of TNF- $\alpha$ were detected by Frodge et al. [4] in all subjects in a clinical trial aiming to determine its correlation with dental connective tissue breakdown. Mean salivary levels of TNF- $\alpha$ were significantly higher in individuals with periodontal disease than in controls. Subjects with salivary TNF- $\alpha$ levels above a threshold of $5.75 \mathrm{pg} / \mathrm{ml}$ had significantly more sites with bleeding on probing and attachment loss $\pm 2 \mathrm{~mm}(\mathrm{P} \leq 0.01)$. This study showed that the salivary levels of TNF- $\alpha$ were elevated in patients who had clinical indicators of periodontitis, suggesting that this biomarker may serve in a panel of salivary biomarkers that could facilitate the screening, diagnosis, and management of periodontal diseases.

Additionally, it was performed a periodontitis experimental model to determine the expression of TNF- $\alpha$ and PGE $_{2}$ in the occurrence and development of periodontitis [22]. After a 6-week period of disease, the animals were sacrificed and the periodontal tissues were obtained. They were then made into slices and histopathological changes were analysed as well as TNF- $\alpha$ and PGE 2 levels changes. The two inflammatory mediators were statistically significantly expressed at higher levels than that in the control group. Other investigation aiming to quantify the TNF- $\alpha$ and other cytokines levels in the gingival tissues of patients with periodontitis, gingival tissues from 19 patients with periodontitis (male, $\mathrm{n}=14$; female, $\mathrm{n}=5$ ) were collected. The level of TNF- $\alpha$ expression was consistently high [20]. These results are suggestive of a strong association of TNF- $\alpha$ with the pathophysiology of periodontitis, and the measurement of this cytokine may be beneficial in the identification of patients with periodontitis.

Evaluating the effect of type 2 diabetes mellitus and smoking on salivary TNF- $\alpha$ level in patients with chronic periodontitis compared to healthy individuals, subjects aged between 30 to 35 years old were included in a study and divided into four groups. The results obtained suggested a strong correlation between TNF- $\alpha$ and periodontal disease in the presence of predisposing factors such as smoking and diabetes, which means that not only does this cytokine play a role in the onset of periodontitis but also its response to external factors exacerbates the disease status (Table 3) [23]. Therefore, TNF- $\alpha$ seems to show a high degree of correlation with the development of periodontal diseases and it can be a salivary biomarker used to search for the development and progression of periodontal diseases.

\section{DISCUSSION}

The traditional diagnosis of periodontal diseases is based on clinical parameters such as bleeding on probing, probing pocket depths, and clinical attachment loss. Albeit easy to use, cost-effective and relatively non-invasive, clinical attachment loss evaluation using the periodontal probe requires a 2 $3 \mathrm{~mm}$ threshold change before a site with significant breakdown can be identified. Yet, this is the most used way to determine whether or not any subject is undergoing periodontal tissue destruction, leading to the irreversible dental loss [24].

However, dental research has developed new technology to help dentists to identify patients who are undergoing pathological processes. In the field of inflammatory research, many studies have been carried out looking at the innovation of diagnosis methods whose advantages could be early detection, a non-invasive approach, high sensitivity and specificity. Thus, this scenario boosts the search for a method capable of diagnosing periodontal diseases in an early fashion, bringing on an era of personalised medicine and individualised clinical decisions. In this regards, it emerges the use of salivary-based diagnosis to which much more attention is currently given.

At present, saliva represents an increasingly useful auxiliary means of diagnosis. Many researchers have made use of sialometry, which measures 
the saliva flow, and sialochemistry, which measures saliva composition, to diagnose systemic illnesses, monitoring general health, and as an indicator of risk for diseases creating a close relation between oral and systemic health. Because serum components of saliva are derived primarily from the local vasculature that originates from the carotid arteries, saliva has a prodigious fluid source that provides many, if not most, of the same molecules found in the systemic circulation. Thus, researchers involved in periodontal disease diagnostics are currently investigating the possible use of oral fluids, such as saliva, for disease assessment. It could be used to monitor the general health and the onset of specific diseases [25].

Many analyses associated with periodontitis have been detected in saliva such as cytokines that are hostderived factors that can provide potentially important information regarding periodontal status [26]. IL$1 \beta$ levels would be associated with periodontal disease onset, severity, and progress as this cytokine showed to have a strong correlation with the many clinical parameters evaluated and might be reliable to predict how an individual responds to periodontal diseases after a treatment. It can be a strong candidate biomarker of periodontal diseases, determining individuals' likelihood to develop such malady, being it, therefore, traceable in human oral fluids.

It would be clear to associate high IL-1 $\beta$ salivary levels to periodontal diseases onset or progress as these diseases are inflammatory-mediated. Consequently, progressing periodontal diseases would be directly correlated with high levels of IL-1 $\beta$ in the whole saliva or in the gingival crevicular fluid. Even more than a cause, IL- $1 \beta$ levels concomitantly rise as the disease initiates and develops which permits cytokine quantification in the saliva of susceptible individuals. Thus, the early detection of increasing IL-1 $\beta$ levels would help anticipate the dental tissue breakdown and, therefore, it would make possible to provide those patients with the proper treatment before the irreversible dental loss.

TNF- $\alpha$ might be able to help us identify periodontitis susceptible patients such as those who suffer from diabetes mellitus or smokers. Moreover, TNF- $\alpha$ would be useful as a traceable salivary inflammatory mediator whose levels could be associated with the disease severity, showing its progression, being this possibility is a powerful tool to provide patients with the most suitable treatment according to their disease stage.
Nonetheless, being present in the oral fluids early, even before the periodontal clinical parameters being present, is a remarkable feature that makes possible the cytokine-based diagnosis of periodontal diseases.

In regards to periodontal diseases, studies are needed to sample patients at regular intervals in order to capture biomarkers profiles seen during different phases of active disease. This information can then be used to identify useful key salivary biomarkers associated with the inflammatory patterns and the bone remodelling process through which a patient may undergo. Obstacles to these approaches may appear in the clinical setting whilst the future of periodontal disease diagnosis using salivary screening looks promising.

The field of salivary diagnostics is new and revolutionary. Its emergent and novel status is prominent and many biomarkers have been investigated, albeit few research centres mainly through cross-sectional and animal studies have done the search for new salivary sensors of periodontal diseases. Therefore, it is relevant that the use of salivary biomarkers applied to the diagnosis of periodontal disease could be even more investigated in order to consolidate the existing data related to this topic.

\section{CONCLUSIONS}

Inflammatory cytokines interleukin-1 beta and tumour necrosis factor-alpha are contributing mediators of periodontal diseases and they are present in the saliva in early stages as well as their levels increased with the disease progression. Therefore, they might show reliability in regards the periodontal disease diagnosis, being useful as biomarkers and promising tools in the early diagnosis of periodontal diseases.

\section{ACKNOWLEDGMENTS AND DISCLOSURE STATEMENTS}

This work was supported by Fundação Cearense de Apoio ao Desenvolvimento Científico e Tecnológico (FUNCAP), Conselho Nacional de Pesquisa (CNPq), Coordenação de Aperfeiçoamento de Pessoal de Nível Superior (CAPES).

The authors declare no conflict of interests regarding the publication of this article. 


\section{REFERENCES}

1. Silva N, Abusleme L, Bravo D, Dutzan N, Garcia-Sesnich J, Vernal R, Hernández M, Gamonal J. Host response mechanisms in periodontal diseases. J Appl Oral Sci. 2015 May-Jun;23(3):329-55. [Medline: 26221929] [PMC free article: $\underline{4510669]}$ [doi: $\underline{10.1590 / 1678-775720140259]}$

2. Sexton WM, Lin Y, Kryscio RJ, Dawson DR 3rd, Ebersole JL, Miller CS. Salivary biomarkers of periodontal disease in response to treatment. J Clin Periodontol. 2011 May;38(5):434-41. [Medline: 21480939] [PMC free article: 3095429] [doi: $10.1111 / \mathrm{j} .1600-051 X .2011 .01706 . x]$

3. da Costa TA, Silva MJ, Alves PM, Chica JE, Barcelos EZ, Giani MA, Garlet GP, da Silva JS, Rodrigues Júnior V, Rodrigues DB, Cardoso CR. Inflammation Biomarkers of Advanced Disease in Nongingival Tissues of Chronic Periodontitis Patients. Mediators Inflamm. 2015;2015:983782. [Medline: 26063981]

4. Frodge BD, Ebersole JL, Kryscio RJ, Thomas MV, Miller CS. Bone remodeling biomarkers of periodontal disease in saliva. J Periodontol. 2008 Oct;79(10):1913-9. [Medline: 18834246] [doi: 10.1902/jop.2008.080070]

5. de Almeida Pdel V, Grégio AM, Machado MA, de Lima AA, Azevedo LR. Saliva composition and functions: a comprehensive review. J Contemp Dent Pract. 2008 Mar 1;9(3):72-80. [Medline: 18335122]

6. de Lima V, Bezerra MM, de Menezes Alencar VB, Vidal FD, da Rocha FA, de Castro Brito GA, de Albuquerque Ribeiro R. Effects of chlorpromazine on alveolar bone loss in experimental periodontal disease in rats. Eur J Oral Sci. 2000 Apr;108(2):123-9. [Medline: 10768725] [doi: 10.1034/j.1600-0722.2000.00766.x]

7. Rosa N, Correia MJ, Arrais JP, Costa N, Oliveira JL, Barros M. The landscape of protein biomarkers proposed for periodontal disease: markers with functional meaning. Biomed Res Int. 2014;2014:569632. [Medline: 25057495]

8. Preshaw PM, Taylor JJ. How has research into cytokine interactions and their role in driving immune responses impacted our understanding of periodontitis? J Clin Periodontol. 2011 Mar;38 Suppl 11:60-84. [Medline: 21323705] [doi: 10.1111/j.1600-051X.2010.01671.x]

9. Ding C, Ji X, Chen X, Xu Y, Zhong L. TNF- $\alpha$ gene promoter polymorphisms contribute to periodontitis susceptibility: evidence from 46 studies. J Clin Periodontol. 2014 Aug;41(8):748-59. [Medline: 24905365] [doi: 10.1111/jepe.12279]

10. Moher D, Liberati A, Tetzlaff J, Altman DG; PRISMA Group. Preferred reporting items for systematic reviews and metaanalyses: the PRISMA statement. Int J Surg. 2010;8(5):336-41. [Medline: 20171303] [doi: 10.1016/j.ijsu.2010.02.007]

11. Chien PF, Khan KS, Siassakos D. Registration of systematic reviews: PROSPERO. BJOG. 2012 Jul;119(8):903-5. [Medline: 22703418] [doi: 10.1111/j.1471-0528.2011.03242.x]

12. Higgins JPT, Green S. Cochrane Handbook for Systematic Reviews of Interventions. [URL: http://www.cochrane.org/ cochrane-interventions-handbook]

13. Ma L, Chu WM, Zhu J, Wu YN, Wang ZL. Interleukin-1 $\beta$ (3953/4) C $\rightarrow$ T polymorphism increases the risk of chronic periodontitis in Asians: evidence from a meta-analysis of 20 case-control studies. Arch Med Sci. 2015 Apr 25;11(2): 267-73. [Medline: 25995740] [PMC free article: 4424246] [doi: 10.5114/aoms.2015.50961]

14. Zhu H, Lin X, Zheng P, Chen H. Inflammatory cytokine levels in patients with periodontitis and/or coronary heart disease. Int J Clin Exp Pathol. 2015 Feb 1;8(2):2214-20. [Medline: 25973132] [PMC free article: 4396332]

15. Oh H, Hirano J, Takai H, Ogata Y. Effects of initial periodontal therapy on interleukin-1 $\beta$ level in gingival crevicular fluid and clinical periodontal parameters. J Oral Sci. 2015 Jun;57(2):67-71. [Medline: 26062853] [doi: 10.2334/josnusd.57.67]

16. Miller CS, King CP Jr, Langub MC, Kryscio RJ, Thomas MV. Salivary biomarkers of existing periodontal disease: a crosssectional study. J Am Dent Assoc. 2006 Mar;137(3):322-9. [Medline: 16570465] [doi: 10.14219/jada.archive.2006.0181]

17. Ng PY, Donley M, Hausmann E, Hutson AD, Rossomando EF, Scannapieco FA. Candidate salivary biomarkers associated with alveolar bone loss: cross-sectional and in vitro studies. FEMS Immunol Med Microbiol. 2007 Mar;49(2):252-60. [Medline: 17328758] [PMC free article: 2258090] [doi: 10.1111/j.1574-695X.2006.00187.x]

18. Scannapieco FA, Ng P, Hovey K, Hausmann E, Hutson A, Wactawski-Wende J. Salivary biomarkers associated with alveolar bone loss. Ann N Y Acad Sci. 2007 Mar;1098:496-7. [Medline: 17435158] [PMC free article: 2254505] [doi: 10.1196/annals.1384.034]

19. Reinhardt RA, Stoner JA, Golub LM, Lee HM, Nummikoski PV, Sorsa T, Payne JB. Association of gingival crevicular fluid biomarkers during periodontal maintenance with subsequent progressive periodontitis. J Periodontol. 2010 Feb;81(2):251-9. [Medline: 20151804] [PMC free article: 2822998] [doi: 10.1902/jop.2009.090374]

20. Noh MK, Jung M, Kim SH, Lee SR, Park KH, Kim DH, Kim HH, Park YG. Assessment of IL-6, IL-8 and TNF- $\alpha$ levels in the gingival tissue of patients with periodontitis. Exp Ther Med. 2013 Sep;6(3):847-851. [Medline: 24137277] [PMC free article: 3786859]

21. Kato Y, Hagiwara M, Ishihara Y, Isoda R, Sugiura S, Komatsu T, Ishida N, Noguchi T, Matsushita K. TNF- $\alpha$ augmented Porphyromonas gingivalis invasion in human gingival epithelial cells through Rab5 and ICAM-1. BMC Microbiol. 2014 Sep 3;14:229. [Medline: 25179218] [PMC free article: 4159534] [doi: 10.1186/s12866-014-0229-Z]

22. Liao CH, Fei W, Shen ZH, Yin MP, Lu C. Expression and distribution of TNF- $\alpha$ and PGE2 of periodontal tissues in rat periodontitis model. Asian Pac J Trop Med. 2014 May;7(5):412-6. [Medline: 25063072] [doi: 10.1016/S1995-7645(14)60067-5] 
23. Singh P, Gupta ND, Bey A, Khan S. Salivary TNF-alpha: A potential marker of periodontal destruction. J Indian Soc Periodontol. 2014 May;18(3):306-10. [Medline: 25024542] [PMC free article: 4095621] [doi: 10.4103/0972-124X.134566]

24. Giannobile WV, Beikler T, Kinney JS, Ramseier CA, Morelli T, Wong DT. Saliva as a diagnostic tool for periodontal disease: current state and future directions. Periodontol 2000. 2009;50:52-64. [Medline: 19388953] [doi: $10.1111 / \mathrm{j} .1600-0757.2008 .00288 . x$ ]

25. Miller CS, Foley JD, Bailey AL, Campell CL, Humphries RL, Christodoulides N, Floriano PN, Simmons G, Bhagwandin B, Jacobson JW, Redding SW, Ebersole JL, McDevitt JT. Current developments in salivary diagnostics. Biomark Med. 2010 Feb;4(1):171-89. [Medline: 20387312] [doi: 10.2217/bmm.09.68]

26. Ebersole JL, Nagarajan R, Akers D, Miller CS. Targeted salivary biomarkers for discrimination of periodontal health and disease(s). Front Cell Infect Microbiol. 2015 Aug 19;5:62. [Medline: 26347856] [PMC free article: 4541326] [doi: $\underline{10.3389 / \text { fcimb.2015.00062] }}$

\section{To cite this article:}

Gomes FI, Aragão MG, Barbosa FC, Bezerra MM, de Paulo Teixeira Pinto V, Chaves HV.

Inflammatory Cytokines Interleukin- $1 \beta$ and Tumour Necrosis Factor- $\alpha$ - Novel Biomarkers for the Detection of Periodontal Diseases: a Literature Review

J Oral Maxillofac Res 2016;7(2):e2

URL: http://www.ejomr.org/JOMR/archives/2016/2/e2/v7n2e2.pdf

doi: $10.5037 /$ jomr.2016.7202

Copyright (C) Gomes FI, Aragão MG, Barbosa FC, Bezerra MM, de Paulo Teixeira Pinto V, Chaves HV. Published in the JOURNAL OF ORAL \& MAXILLOFACIAL RESEARCH (http://www.ejomr.org), 30 June 2016.

This is an open-access article, first published in the JOURNAL OF ORAL \& MAXILLOFACIAL RESEARCH, distributed under the terms of the Creative Commons Attribution-Noncommercial-No Derivative Works 3.0 Unported License, which permits unrestricted non-commercial use, distribution, and reproduction in any medium, provided the original work and is properly cited. The copyright, license information and link to the original publication on (http://www.ejomr.org) must be included. 